\title{
Influence of fermentation time on characteristics of sourdough bread
}

\author{
Krischina Singer Aplevicz*, Paulo José Ogliari, Ernani Sebastião Sant’Anna \\ Department of Food Science and Technology, Federal University of Santa Catarina
}

\begin{abstract}
Sourdough is used in the manufacture of numerous baked products. The microorganisms used in this preparation of sourdoughs included two strains from the Lactobacillus paracasei (1 and 2) and two strains from the Saccharomyces cerevisiae group (1 and 2). Samples of raw dough were analyzed for $\mathrm{pH}$, titratable acidity and plate counts and samples of resulting bread were analyzed for $\mathrm{pH}$, titratable acidity and specific volume. The samples were analyzed every $2 \mathrm{~h}$, between 4 and $10 \mathrm{~h}$ of fermentation. After 10 hours of fermentation, the lowest values of $\mathrm{pH}$ were for dough with LC2 and bread with SC1. Titratable acidity values increased over time, with the highest levels of acidity were found in the dough and bread with yeasts. Lactic acid bacteria showed the highest microbial counts over time. With the exception of SC2, the greatest microbial increases occurred at 10 hours of fermentation. LC1 showed the lowest volume across all time points $(\mathrm{p}<0.05)$. The largest volumes were found in breads after 6 hours of fermentation. $\mathrm{SC} 1$ showed the best specific volume values across all times tested.
\end{abstract}

Uniterms: Sourdough. Bread. Lactic acid bacteria. Yeast. Linear regression.

O fermento natural é usado no processamento de vários produtos de panificação. Os micro-organimos usados no preparo dos fermentos foram duas cepas de Lactobacillus paracasei (1 e 2) e duas cepas de Saccharomyces cerevisiae (1 e 2). Das amostras de massa crua, foi analisado o pH, a acidez titulável e a contagem em placas e das amostras do pão, foi analisado o $\mathrm{pH}$, a acidez titulável e o volume específico. As amostras foram analisadas num intervalo de $2 \mathrm{~h}$, entre 4 e $10 \mathrm{~h}$ de fermentação. Ao final, os menores valores de $\mathrm{pH}$ foram para a massa crua com LC2 e o pão com SC1. Os valores de acidez titulável aumentaram ao longo do tempo, apresentando os maiores teores de acidez a massa e o pão com leveduras. As bactérias láticas apresentaram as maiores contagens microbiológicas ao longo do tempo. Com exceção de SC2, os maiores crescimentos microbianos foram com $10 \mathrm{~h}$ de fermentação. LC1 apresentou menor volume em todas as horas $(\mathrm{p}<0.05)$. Os maiores volumes encontrados nos pães foram com $6 \mathrm{~h}$ de fermentação. $\mathrm{SC} 1$ apresentou os melhores resultados de volume específico durante todo o período.

Unitermos: Fermento natural. Pão. Bactéria lática. Levedura. Regressão linear.

\section{INTRODUCTION}

Due to increasing consumer demand for more natural, tastier and healthier food, the traditional process of sourdough bread production has enjoyed renewed success in recent years (Brümmer, Lorenz, 1991; Thiele et al., 2002; Lopez et al., 2003). Sourdough is employed in the manufacture of a number of baked products, such

\footnotetext{
*Correspondence: K. S. Aplevicz. Departamento de Ciência e Tecnologia de Alimentos, Universidade Federal de Santa Catarina. Rod. Admar Gonzaga, 1346 - Itacorubi - 88034-001 - Florianópolis - SC, Brasil. Email: aplevicz@gmail.com
}

as breads, cakes and crackers (De Vuyst, Gänzle, 2005).

Gocmen et al. (2007) and Thiele et al. (2002) reported that the application of sourdough to wheat breads produced several effects, including leavening, acidification, improvement of the dough properties, flavor of the bread, texture, delayed firmness and staling, increased resistance to microbial spoilage and improved nutrient availability of cereals. It was suggested that all these benefits were attributable to the acid lactic bacteria (LAB) and yeasts naturally present in sourdough.

Moreover, it has been noted that when sourdough is added, there are changes in the fundamental rheological properties of wheat dough, making it soft, less elastic 
and therefore easily extendable (Clarke et al., 2002). The impact of changes in the rheology of dough must be considered in order to choose an appropriate fermentation time and obtain good quality bread. The dough must contain a large volume of gas and also reserve gas retention for oven rise (Bloksma, 1990).

However, there are other factors to be taken into account, such as the type of flour, the sourdough fermentation conditions ( $\mathrm{pH}$ and temperature) and the selection of starter cultures with specific and desirable metabolic properties (De Vuyst, Vancanneyt, 2007). In this study, the influence of fermentation time on sourdough in terms of $\mathrm{pH}$, titratable acidity, microbiological counts and volume of dough and bread, was analyzed.

\section{MATERIAL AND METHODS}

\section{Microorganisms}

The microorganisms used included two strains from the Lactobacillus paracasei (1 and 2) and two strains from the Saccharomyces cerevisiae (1 and 2). The lactic acid bacteria from the Lactobacillus paracasei (LP1 - 9.4 log CFU/g and LP2 - $11.11 \log \mathrm{CFU} / \mathrm{g}$ ) and yeasts from Saccharomyces cerevisiae 1 (SC1 $8.18 \log \mathrm{CFU} / \mathrm{g}$ and SC2 - $7.16 \log \mathrm{CFU} / \mathrm{g}$ ) were isolated from grape sourdough, phenotypically and genotypically characterized, freeze dried and applied in this study.

\section{Sourdough preparation}

Separate sourdoughs were prepared with each strain. The amount of microorganisms used was $1 \%(\mathrm{w} / \mathrm{w}$ on flour basis, Plessas et al., 2008) and fermented for 48 hours. Dough 1 (D1) was prepared by mixing $60 \mathrm{~mL}$ of tap water, $50 \mathrm{~g}$ of wheat flour and $0.25 \mathrm{~g}$ of $\mathrm{NaCl}$ incubated at $30{ }^{\circ} \mathrm{C}$. After 24 hours' incubation, sourdough 1 (SD1) was obtained. Subsequently, $100 \mathrm{~g}$ of SD1 was mixed with $200 \mathrm{~g}$ of wheat flour and $100 \mathrm{~mL}$ of tap water to form dough 2 (D2). After 24 hours incubation, sourdough 2 (SD2) was produced, according to the procedure of Paramithiotis et al. (2005), with modifications.

\section{Dough and bread analyses}

Samples of raw dough were analyzed for $\mathrm{pH}$, titratable acidity (TTA) and plate counts while samples of bread were analyzed for $\mathrm{pH}$, titratable acidity and specific volume. These analyses were carried out every 2 hours, between 4 and 10 hours of fermentation.

The $\mathrm{pH}$ value was recorded and acidity titrated using
$0.1 \mathrm{~N} \mathrm{NaOH}$ (Brasil, 2004). The TTA was expressed in $\mathrm{mL} 0.1 \mathrm{~N} \mathrm{NaOH} / 100 \mathrm{~g}$. The evaluation of growth was determined by counting the number of viable cells in logarithms $(\log \mathrm{UFC} / \mathrm{g})$ using the pour plate method (Silva et al., 2010). Aseptically, $25 \mathrm{~g}$ of each dough was mixed

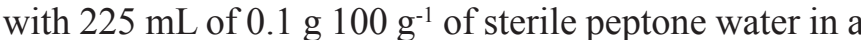
bag mixer (model P, Interscience, St. Nom, France). The necessary dilutions of $\mathrm{LAB}$ and yeast were performed. LAB were grown on MRS Agar at $30{ }^{\circ} \mathrm{C} / 48$ hours and yeasts were grown on PDA Agar with tartaric acid (10\%) at $25{ }^{\circ} \mathrm{C} / 72$ hours. All experiments were carried out in triplicate.

\section{Bread making}

The sourdoughs were applied in breads, whose formulation consisted of a compound of $100 \%$ wheat flour, $20 \%$ sourdough (Katina et al., 2006a; Paramithiotis et al., 2005; Plessas et al., 2011; Robert et al., 2006), 60\% water and $1.8 \%$ salt.

After mixing the ingredients, about $24 \mathrm{~g}$ of resultant dough was weighed out and fermented in a fermentation chamber (model CFC P-20, Perfecta, Curitiba, Brazil) at $30{ }^{\circ} \mathrm{C}$ for $4,6,8$ and $10 \mathrm{~h}(80 \%$ relative humidity) and then cooked (model ventile E-6, Líder, Araucária, Brazil) at $180^{\circ} \mathrm{C}$ for $18 \mathrm{~min}$.

\section{Specific volume}

Loaf volume was measured using the rapeseed replacement method described by Hallén et al. (2004). Each loaf was placed in a metal container with a known volume $\left(\mathrm{V}_{\mathrm{C}}\right)$. The container was then topped up with rapeseed, the loaf removed and the volume of the rapeseed measured $\left(\mathrm{V}_{\mathrm{R}}\right)$. Loaf volume $\left(\mathrm{V}_{\mathrm{L}}\right)$ was then calculated and recorded according to Equation 1.

$$
\mathrm{V}_{\mathrm{L}}(\mathrm{mL})=\mathrm{V}_{\mathrm{C}}-\mathrm{V}_{\mathrm{R}}
$$

After cooling for $1 \mathrm{~h}$, the same loaves used for measuring volume were weighed on digital scales, W (g). Specific volume $\left(\mathrm{V}_{\mathrm{S}}\right)$ of bread was calculated according to Equation 2.

$$
\mathrm{V}_{\mathrm{S}}(\mathrm{mL} / \mathrm{g})=\mathrm{V}_{\mathrm{L}} / \mathrm{W} \quad \text { Eq.2 }
$$

\section{Statistical analysis}

Statistical analyses were performed using the Statistica ${ }^{\circledR}$ software version 8.0 (Statsoft Inc., Tulsa, OK, USA). The behavior of the raw dough and bread, 
prepared using sourdough with LC1, LC2, SC1 and SC2, over the period between 4 and 10 hours of fermentation was studied by a simple linear regression model, given by $Y=\beta_{0}+\beta_{1} X+{ }_{\varepsilon}$, where $X$ is the fermentation time, expressed in hours. Differences between the means were established using one-way analysis of variance (ANOVA) followed by Tukey's test. Differences at the $5 \%$ level of significance $(\mathrm{p}<0.05)$ were considered statistically significant.

\section{RESULTS AND DISCUSSION}

\section{Dough and bread evaluation}

The estimated equation of analysis of linear regression for $\mathrm{pH}$, titratable acidity, and plate counts for raw dough, between 4 and $10 \mathrm{~h}$ of fermentation, are shown in Figure 1 ( $\mathrm{A}, \mathrm{B}$ and $\mathrm{C}$ ) whereas $\mathrm{pH}$, titratable acidity and specific volume for breads, between 4 and $10 \mathrm{~h}$ of fermentation, are shown in Figure 2 (A, B and C).

The $\mathrm{pH}$ values of dough and bread declined with longer fermentation time. The initial $\mathrm{pH}$ of dough and breads at $4 \mathrm{~h}$ of fermentation ranged from 4.51 to $4.73 \pm 0.01$ and 4.45 to $4.74 \pm 0.01$, respectively. At the end of the fermentation period of $10 \mathrm{~h}$, the lowest $\mathrm{pH}$ values were for dough with LP2 $(3.44 \pm 0.04)$ and for bread with $\mathrm{SC} 1(2.99 \pm 0.05)$. The analysis of regression indicated that the rates of decrease in $\mathrm{pH}$ of dough (Figure 1A) and of bread (Figure $2 \mathrm{~A})$, were statistically equal $(\mathrm{p}>0.05)$.

Therefore, the null hypothesis $\left(\mathrm{H}_{0}\right)$ was not rejected by the $\mathrm{F}$ test at the significance level of $5 \%$, where $\mathrm{H}_{0}$ indicates that angular coefficients were equal. In the analysis of $\mathrm{pH}$ of dough, a higher coefficient of determination was observed for yeasts (SC2: 0.8832; SC1: 0.8723; LP2: 0.8416: LP1: 0.8094), while for the $\mathrm{pH}$ of breads LAB had the highest $\mathrm{r}^{2}$ (LP2: 0.9512; LP1: 0.9162; SC1: 0.9061; SC2: 0.8831). Among many important effects, the drop in $\mathrm{pH}$ value caused by organic acids exerted an influence on the viscoelastic behavior of dough (Wehrle, Arendt, 1998).

The titratable acidity values increased over time, with the highest levels of acidity found for dough and bread with yeast. SC2 showed the highest acidity of dough production at all-time points $(5.08 \pm 0.41 ; 5.52 \pm 0.16$; $5.68 \pm 0.10 ; 6.51 \pm 1.32)$, followed by SC1 ( $4.70 \pm 0.13$; $5.19 \pm 0.49 ; 5.52 \pm 0.01 ; 6.42 \pm 0.13)$. Analyses of linear regression of increased acidity of the dough (Figure 1B) using the $\mathrm{F}$ test for contrast of coefficients, indicated a significant difference between the linear and angular coefficients of LP1/SC2 and linear coefficient of LP2/ SC1 $(p<0.05)$. The highest coefficient of determination was found in titratable acidity for SC1, followed by LP1; SC2 and LP2 $\left(\mathrm{r}^{2}=0.9564 ; 0.9459 ; 0.9225 ; 0.9080\right)$.

For the analysis of titratable acidity of bread (Figure 2B), a significant difference was noted between linear and angular coefficients LP1/SC1 and $\mathrm{SC} 1 / \mathrm{SC} 2$; angular coefficients of LP2/ SC2 and the linear coefficient of LP2/SC1 $(p<0.05)$. The highest coefficient of determination was LP1, followed by LP2; SC2 and SC1 $\left(r^{2}=0.9801 ; 0.9196 ; 0.9138 ; 0.8296\right)$.

The acidification process, affected by the application of sourdough, is mainly used to improve quality, taste and flavor of wheat breads (Brümmer, Lorenz, 1991; Katina et al., 2006a; Arendt et al., 2007) and to delay staling (Katina et al., 2006b; Plessas et al., 2007). The use of salt has a marked effect on both LAB growth and acid production and can be used as a method of controlling overall bread acidity (Simonsom et al., 2003).

LAB showed the highest counts over time. With the exception of SC2, the highest microbial growth occurred after 10 hours of fermentation, the highest value was for LP2 with $8.91 \log$ CFU/g, followed by LP1 with $8.66 \log \mathrm{CFU} / \mathrm{g}$, SC1 with $8.03 \log \mathrm{CFU} / \mathrm{g}$. At the same time, SC2 showed a drop of $0.21 \log \mathrm{CFU} / \mathrm{g}$. At 6 hours of fermentation, LP2 obtained $8.66 \log$ CFU/g and LP1 $8.33 \log \mathrm{CFU} / \mathrm{g}$. Yeasts showed $7.18 \log \mathrm{CFU} / \mathrm{g}$ for $\mathrm{SC} 1$ and $7.08 \log \mathrm{CFU} / \mathrm{g}$ for SC2 (Figure 1C).

Plate counts of $\mathrm{LAB}$ and yeasts during spontaneous fermentation of maize flour were previously studied by Edema and Sanni (2008). LAB counts increased steadily from $4.62 \log \mathrm{CFU} / \mathrm{g}$ at mixing $(0 \mathrm{~h})$ to $6.45 \log \mathrm{CFU} / \mathrm{g}$ after 48 hours fermentation while yeast counts increased from 4.18 to $6.64 \log \mathrm{CFU} / \mathrm{g}$ over the same period of fermentation.

For plate counts, the analysis of regression indicated that the angular and linear coefficients of LP1/LP2 were statistically the same $(\mathrm{p}>0.05)$, as were the linear coefficients of LP2/SC2 and LP2/SC2. All other contrasts revealed a statistical difference between treatments $(p<0.05)$. The highest coefficient of determination $\left(\mathrm{r}^{2}\right)$ for plate count was with $\mathrm{SC} 1$ at 0.9674 , indicating that the adjustment of the regression explains $96.74 \%$ of total variation in $\mathrm{Y}$, but only $3.26 \%$ for the residual variation (error), considered a good fit.

Analysis of regression of specific volume (Figure $2 \mathrm{C}$ ) indicated that all the linear coefficients were statistically different $(\mathrm{p}<0.05)$. The highest coefficients of determination $\left(\mathrm{r}^{2}\right)$ for yeasts were SC1 and SC2 (0.7975; 0.7909). LC1 and LC2 showed the lowest volume across all hours tested $(\mathrm{p}<0.05)$, where this occurred because they constitute facultative heterofermentative lactic bacteria. 
Lactobacillus can be divided into three groups, with the final product as a criterion of their fermentation: Lactobacillus thermophilic obligatory homofermentatives,

(a) $\quad \mathrm{pH}$

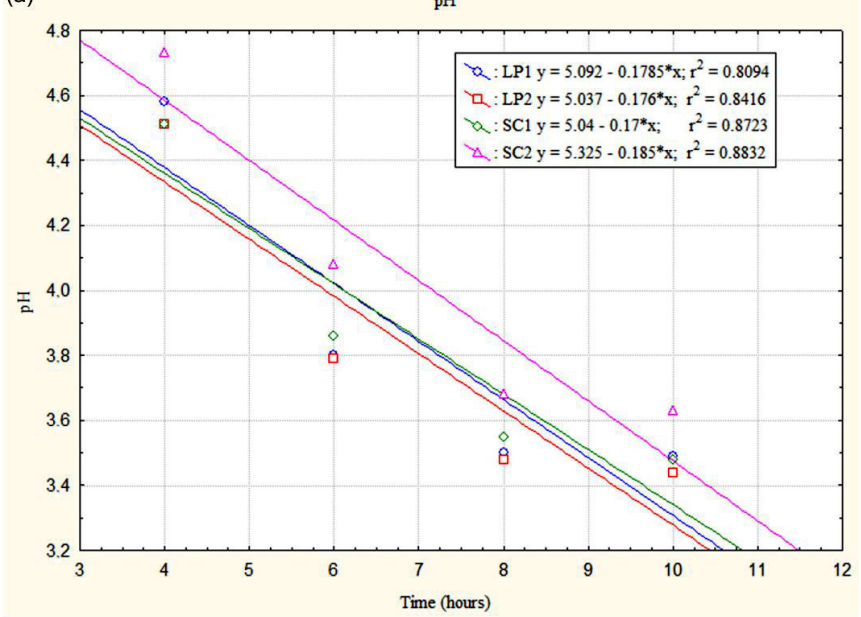

(b)

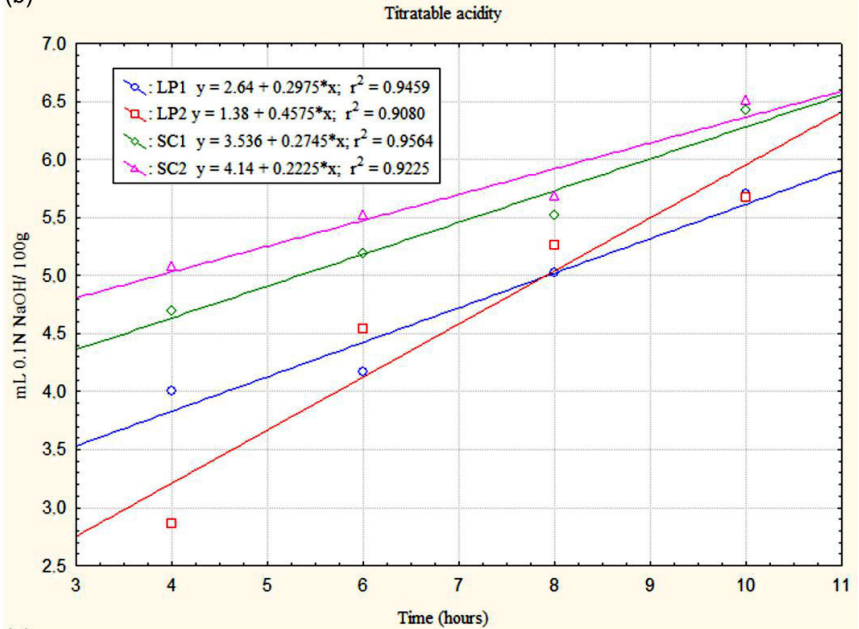

(c)

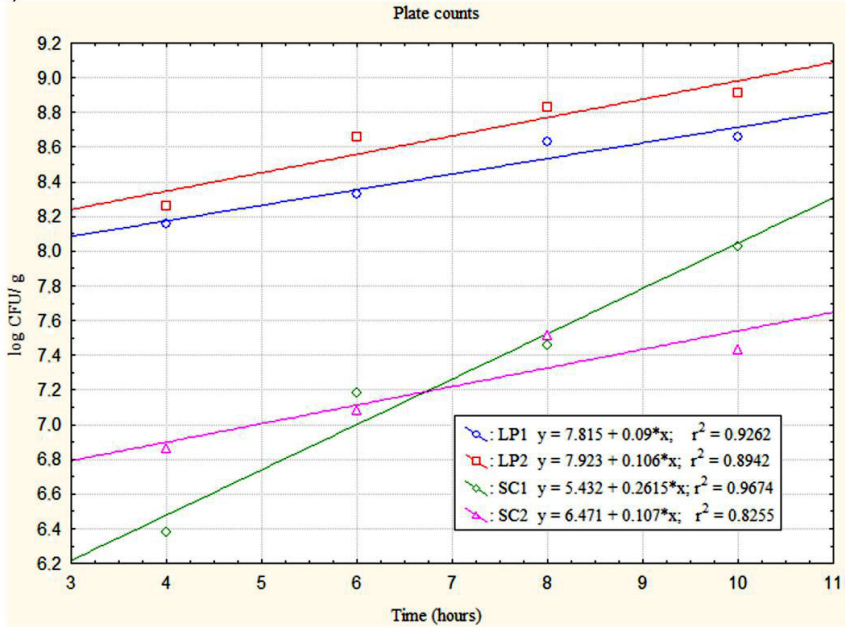

FIGURE 1 - Evolution of pH (a), titratable acidity, (b) and plate counts (c) of raw bread dough between 4 and 10 hours of fermentation. that ferment only hexoses and lactic acid (Lactobacillus delbrueckii subsp. bulgaricus, Lactobacillus delbrueckii subsp. lactis and Lactobacillus helveticus); Lactobacillus

(a) (a) $\mathrm{pH}$

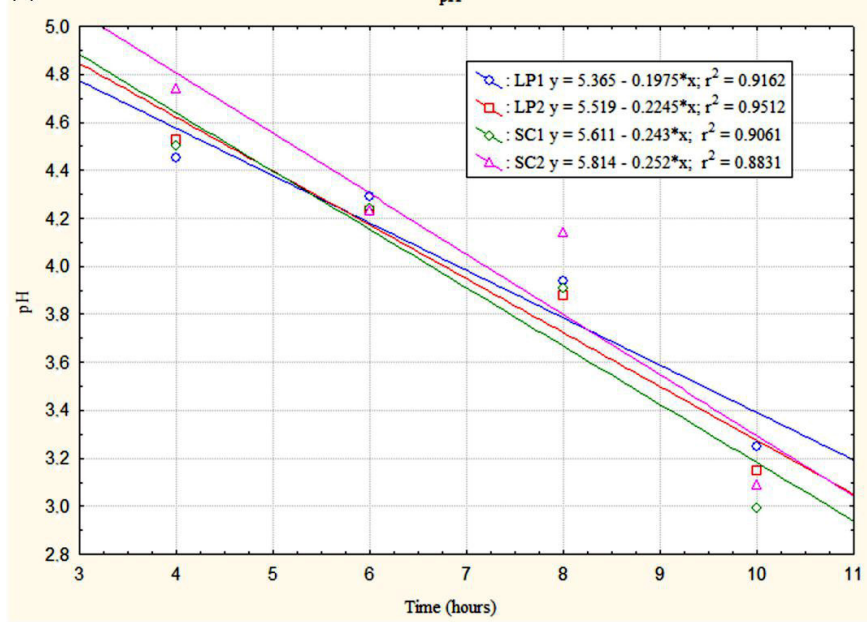

(b)

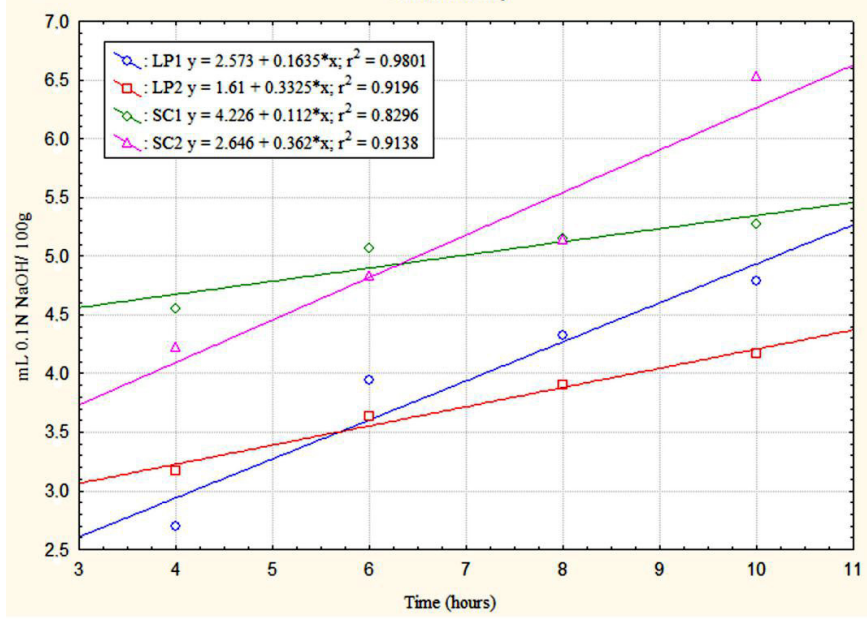

(c)

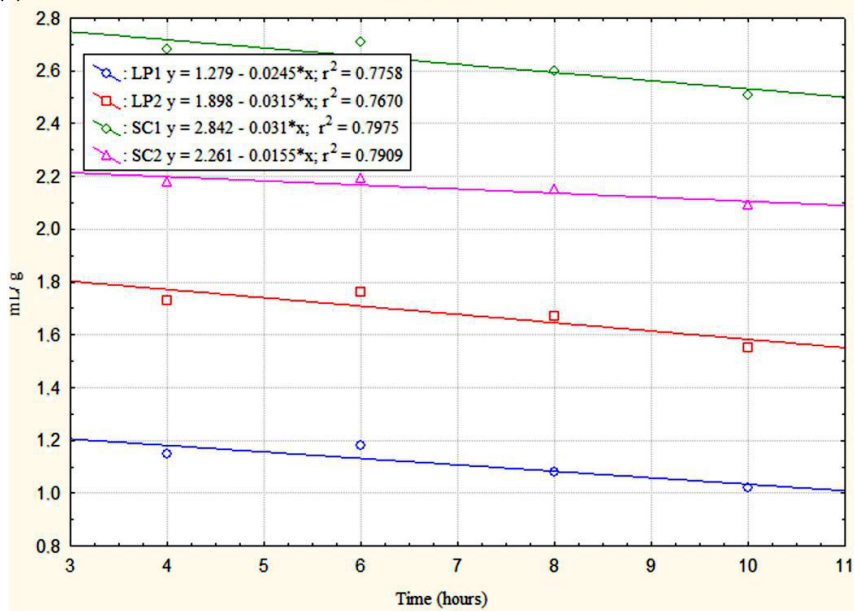

FIGURE 2 - Evolution of pH (a), titratable acidity (b) and specific volume (c) of bread between 4 and 10 hours of fermentation. 
TABLE I - Specific volume of breads produced from about $24 \mathrm{~g}$ dough pieces

\begin{tabular}{lcccc}
\hline Samples & $\mathbf{4 h}$ & $\mathbf{6 ~ h}$ & $\mathbf{8 ~ h}$ & $\mathbf{1 0 ~ h}$ \\
\hline LP1 & $1.15 \pm 0.03^{\mathrm{a}}$ & $1.18 \pm 0.04^{\mathrm{a}}$ & $1.08 \pm 0.04^{\mathrm{a}}$ & $1.02 \pm 0.03^{\mathrm{a}}$ \\
LP2 & $1.73 \pm 0.15^{\mathrm{b}}$ & $1.76 \pm 0.10^{\mathrm{a}, \mathrm{b}}$ & $1.67 \pm 0.07^{\mathrm{b}}$ & $1.55 \pm 0.08^{\mathrm{b}}$ \\
$\mathrm{SC} 1$ & $2.68 \pm 0.08^{\mathrm{c}}$ & $2.71 \pm 0.22^{\mathrm{c}}$ & $2.60 \pm 0.10^{\mathrm{c}}$ & $2.51 \pm 0.17^{\mathrm{c}}$ \\
SC2 & $2.18 \pm 0.03^{\mathrm{d}}$ & $2.19 \pm 0.37^{\mathrm{b}, \mathrm{c}}$ & $2.15 \pm 0.09^{\mathrm{d}}$ & $2.09 \pm 0.07^{\mathrm{d}}$ \\
\hline
\end{tabular}

Results expressed as mean values of triplicates \pm standard deviation.

${ }^{a-d}$ Different superscript letters in the same column between samples denote significant differences (Tukey's test, $\mathrm{p}<0.05$ ).

mesophilic facultative heterofermentatives, which are able to ferment other carbon sources beyond these hexoses, producing organic acids, $\mathrm{CO}_{2}$, alcohol and $\mathrm{H}_{2} \mathrm{O}_{2}$ (Lactobacillus casei, Lactobacillus paracasei and Lactobacillus plantarum); and Lactobacillus mesophilic obligatory heterofermentatives that use principally hexoses and pentoses as carbon source, fermenting hexose and lactic acid, acetic acid, ethanol and $\mathrm{CO}_{2}$ and pentoses to lactic acid and acetic acid (Lactobacillus brevis, Lactobacillus fermentum) (Fox et al., 2000). The species Lactobacillus casei, Lactobacillus paracasei and Lactobacillus rhamnosus belong to the "Lactobacillus casei Group" and are of great commercial value to the food industry (Ferrero et al., 1996).

The highest specific volumes in bread were found at 6 hours of fermentation (Table 1). SC1 showed better results across all times, followed by $\mathrm{SC} 2$. SC1 obtained at 6 hours of fermentation showed the best results, with $2.71 \mathrm{~mL} / \mathrm{g}(\mathrm{p}<0.05)$. Saccharomyces cerevisiae is used in the preparation of bread because it produces a dough with structure and has the ability to retain gas. After 6 hours of fermentation, an influence inversely proportional to TTA increase, with a decrease in volume over time can be observed.

Sanz-Penella et al. (2012) used Bifidobacteria pseudocatenulatum as a starter in sourdough fermentation and reported that fermented dough with $20 \%$ sourdough yielded TTA values of $9.23 \pm 0.32 \mathrm{~mL} \mathrm{NaOH} 0.1 \mathrm{~N} / 100 \mathrm{~g}$ and $\mathrm{pH}$ of $4.57 \pm 0.11$; while bread with $\mathrm{LAB}$ and yeast yielded TTA of $10.60 \pm 0.41 \mathrm{~mL} \mathrm{NaOH} 0.1 \mathrm{~N} / 100 \mathrm{~g}$ and $\mathrm{pH}$ of $4.96 \pm 0.06$. The sample volume increased with $20 \%$ sourdough content showed a significantly lower bread specific volume than the control, with $2.22 \pm 0.12 \mathrm{~mL} / \mathrm{g}$. Crowley et al. (2002) reported that bread specific volume significantly in bread containing $20 \%$ sourdough $(3.40 \pm 0.08 \mathrm{~mL} / \mathrm{g})$.

However, Collar et al. (1994) developed lower volume breads when using a high percentage of sourdough with $L$. plantarum and L. brevis as starters. The acidification of the sourdough and partial acidification of the bread dough have an impact on structure-forming components such as gluten and starch. During incubation of sourdough and dough fermentation, biochemical changes occur in the carbohydrate and protein components of flour owing to the action of microbial and endogenous enzymes (Rollan et al., 2005). There is strong consensus with regard to the positive effects of the addition of sourdough on bread volume and crumb structure (Arendt et al., 2007).

\section{CONCLUSION}

The $\mathrm{pH}$ values of the dough and bread declined with longer fermentation time. Saccharomyces cerevisiae 2 showed the highest production of acidity of dough over all times studied. LAB showed the highest microbiological counts at between 4 and 10 hours. Lactobacillus paracasei 1 showed the lowest specific volume for all hours tested $(p<0.05)$. The best fermentation time of breads found in this study was 6 hours, evidenced by the largest volumes. The two strains exhibited different characteristics in the analyses performed, despite being of the same species.

\section{ACKNOWLEDGEMENTS}

The authors wish to thank the Conselho Nacional de Desenvolvimento Científico e Tecnológico (CNPq), Brazil, for their financial support.

\section{REFERENCES}

ARENDT, E.K.; RYAN, L.A.M.; DAL BELLO, F. Impact of sourdough on the texture of bread. Food Microbiol., v.24, n.2, p.165-174, 2007.

BLOKSMA, A.H. Rheology of the breadmaking process Cereal Foods World, v.35, n.2, p.228-236, 1990.

BRÜMMER, J.M.; LORENZ, K. European developments in wheat sourdoughs. Cereal Foods World, v.36, n.3, p.310$314,1991$. 
CLARKE, C.I.; SCHOBER, T.J.; ARENDT, E.K. Effect of single strain and traditional mixed strain starter cultures on rheological properties of wheat dough and on bread quality. Cereal Chem., v.79, n.5, p.640-647, 2002.

COLLAR, C.; BENEDITO DE BARBER, C.; MARTINEZANAYA, M.A. Microbial sourdoughs influence acidification properties and breadmaking potential of wheat dough. $J$. Food Sci., v.59, n.3, p.629-633, 1994.

CROWLEY, P.; SCHOBER, T.J.; CLARKE, C.I.; ARENDT, E.K. The effect of storage time on textural and crumb grain characteristics of sourdough wheat bread. Eur. Food Res. Technol., v.214, n.6, p.489-496, 2002.

DE VUYST, L.; GÄNZLE, M. Second international symposium on sourdough: from fundamentals to applications. Trends Food Sci. Tech., v.16, n.1, p.2-3, 2005.

DE VUYST, L.; VANCANNEYT, M. Biodiversity and identification of sourdough lactic acid bacteria. Food Microbiol., v.24, n.2, p.120-127, 2007.

EDEMA, M.O.; SANNI, A.I. Functional properties of selected starter cultures for sour maize bread. Food Microbiol., v.25, n.4, p.616-625, 2008.

FERRERO, M.; CESENA, C.; MORELLI, L.; SCOLARI, G.; VESCOVO, M. Molecular characterization of Lactobacillus casei strains. FEMS Microbiol. Lett., v.140, n.2-3, p.215$219,1996$.

FOX, P.F.; MCSWEENEY, P.L.H.; COGAN, T.M.; GUINEE, T.P. Fundamentals of cheese science. Gaithersburg: Aspen Publishiers, 2000. 587 p.

GOCMEN, D.; GURBUZ, O.; KUMRAL, A.Y.; DAGDELEN, A.F.; SAHIN, I. The effects of wheat sourdough on glutenin patterns, dough rheology and bread properties. Eur. Food Res. Technol., v.225, n.5-6, p.821-830, 2007.

HALLÉN, E.; İBANOĞLU, Ş.; AINSWORTH, P. Effect of fermented/germinated cowpea flour addition on the rheological and baking properties of wheat flour. J. Food Eng., v.63, n.2, p.177-184, 2004.

BRASIL. Ministério da Saúde. Instituto Adolfo Lutz. Métodos físico-químicos para análise de alimentos. 4 ed. São Paulo, 2004. 1018 p.
KATINA, K.; HEINIÖ, R.L.; AUTIO, K.; POUTANEN, K. Optimization of sourdough process for improved sensory profile and texture of wheat bread. LWT-Food Sci. Technol., v.39, n.10, p.1189-1202, 2006a.

KATINA, K.; SALMENKALLIO-MARTTILA, M.; PARTANEN, R.; FORSSELL, P.; AUTIO, K. Effects of sourdough and enzymes on staling of high-fibre wheat bread. LWT-Food Sci. Technol., v.39, n.5, p.479-491, 2006b.

LOPEZ, H.W.; DUCLOS, V.; COUDRAY, C.; KRESPINE, V.; FEILLET-COUDRAY, C.; MESSAGER, A.; DEMIGNÉ, C.; RÉMÉSY, C. Making bread with sourdough improves mineral bioavailability from reconstituted whole wheat flour in rats. Nutrition, v.19, n.6, p.524-530, 2003.

PARAMITHIOTIS, S.; CHOULIARAS, Y.; TSAKALIDOU, E.; KALANTZOPOULOS, G. Application of selected starter cultures for the production of wheat sourdough bread using a traditional three-stage procedure. Process Biochem., v.40, n.8, p.2813-2819, 2005.

PLESSAS, S.; ALEXOPOULOS, A.; BEKATOROU, A.; MANTZOURANI, I.; KOUTINAS, A.A.; BEZIRTZOGLOU, E. Examination of freshness degradation of sourdough bread made with kefir through monitoring the aroma volatile composition during storage. Food Chem., v.124, n.2, p.627-633, 2011.

PLESSAS, S.; BEKATOROU, A.; KANELLAKI, M.; KOUTINAS, A.A.; MARCHANT, R.; BANAT, I.M. Use of immobilized cell biocatalysts in baking. Process Biochem., v.42, n.8, p.1244-1249, 2007.

PLESSAS, S.; FISHER, A.; KOURETA, K.; PSARIANOS, C.; POONAM, N.; ATHANASIOS, A.K. Application of Kluyveromyces marxianus, Lactobacillus delbrueckii ssp. bulgaricus and L. helveticus for sourdough bread making. Food Chem., v.106, n.3, p.985-990, 2008.

ROBERT, H.; GABRIEL, V.; LEFEBVRE, D.; RABIER, P.; VAYSSIER, Y.; FONTAGNÉ-FAUCHER, C. Study of the behaviour of Lactobacillus plantarum and Leuconostoc starters during a complete wheat sourdough breadmaking process. LWT-Food Sci. Technol., v.39, n.3, p.256-265, 2006. 
ROLLAN, G.; DE ANGELIS, M.; GOBBETTI, M.; DE VALDEZ, G.F. Proteolytic activity and reduction of gliadinlike fractions by sourdough lactobacilli. J. Appl. Microbiol., v.99, n.6, p.1495-1502, 2005.

SANZ-PENELLA, J.M.; TAMAYO-RAMOS, J.A.; HAROS, M. Application of bifidobacteria as starter culture in whole wheat sourdough breadmaking. Food Biol. Technol., v.5, n.6, p.2370-2380, 2012.

SILVA, N.; JUNQUEIRA, V.C.A.; SILVEIRA, N.F.A.; TANIWAKI, M.H.; SANTOS, R.F.S.; GOMES, R.A.R. Manual de métodos de análise microbiológica de alimentos e água. São Paulo: Varela, 2010. 624 p.

SIMONSON, L.; SALOVAARA, H.; KORHOLA, M. Response of wheat sourdough parameters to temperature, $\mathrm{NaCl}$ and sucrose variations. Food Microbiol., v.20, n.2, p.193-199, 2003
THIELE, C.; GANZLE, M.G.; VOGEL, R.F. Contribution of sourdough lactobacilli, yeast and cereal enzymes to the generation of amino acids in dough relevant for bread flavour. Cereal Chem., v.79, n.1, p.45-51, 2002.

WEHRLE, K.; ARENDT, E.K. Rheological changes in wheat sourdough during controlled and spontaneous fermentation. Cereal Chem., v.75, n.6, p.882-886, 1998.

Received for publication on $10^{\text {th }}$ October 2012 Accepted for publication on $08^{\text {th }}$ March 2013 